\title{
Highly efficient Heck olefin arylation in the presence of iminophosphine-palladium(0) complexes
}

\author{
Alberto Scrivanti ${ }^{\mathrm{a}, *}$, Matteo Bertoldini ${ }^{\mathrm{a}}$, Ugo Matteoli ${ }^{\mathrm{a}}$, Valentina Beghetto ${ }^{\mathrm{a}}$, \\ Simonetta Antonaroli ${ }^{\mathrm{b}}$, Alessia Marini ${ }^{\mathrm{b}}$, Bruno Crociani ${ }^{\mathrm{b}}$ \\ a Dipartimento di Chimica, Università "Cà Foscari” di Venezia, Calle Larga S. Marta 2137, 31023 Venezia, Italy \\ b Dipartimento di Scienze e Tecnologie Chimiche, Università di Roma "Tor Vergata", 00173 Roma, Italy
}

Received 28 October 2004; accepted 2 December 2004

Available online 27 April 2005

\begin{abstract}
The Heck coupling of aryl bromides with olefins such as styrene or butyl acrylate is efficiently catalysed by the iminophosphine-palladium(0) complex $[\mathrm{Pd}(\mathrm{dmfu})(\mathrm{P}-\mathrm{N})]\left(\mathrm{dmfu}=\right.$ dimethyl fumarate; $\left.\mathrm{P}-\mathrm{N}=2-\left(\mathrm{PPh}_{2}\right) \mathrm{C}_{6} \mathrm{H}_{4}-1-\mathrm{CH}=\mathrm{NC}_{6} \mathrm{H}_{4} \mathrm{OMe}-4\right)(\mathbf{1})$ in polar solvents. With activated aryl bromides such as 4-bromoacetophenone turnover numbers of up to 20,000 can be achieved at $140{ }^{\circ} \mathrm{C}$ in $2 \mathrm{~h}$. The presence of electron-donating groups leads to decreased reaction rates, nevertheless, high substrate conversions can be obtained in reasonable reaction times. Kinetic studies indicate that complex $\mathbf{1}$ is only a precursor of the actual catalytic species. Experiments aimed to demonstrate the intervention of metallic palladium did not lead to conclusive findings.
\end{abstract}

(C) 2005 Elsevier B.V. All rights reserved.

Keywords: Palladium; Iminophosphine-palladium(0) complexes; Heck reaction; Aryl bromides

\section{Introduction}

The Heck arylation reaction is one of the most important methods for the formation of new $\mathrm{C}-\mathrm{C}$ bonds (Scheme 1) [1].

The most commonly used catalysts are palladium species in combination with phosphines [2] or other neutral ligands such as heterocyclic carbenes [3], and nitrogen [4] or sulfur ligands [5]. Alternatively, there is a wide variety of phosphorus [3b,6], nitrogen [7] and sulfur [8] containing palladacycles which are able to efficiently catalyse the reaction. For an industrial application, the development of "ligand-free" palladium catalytic systems appears particularly interesting [1c,9].

Recently, we have reported that the iminophosphinepalladium(0) complex $\mathbf{1}$ (Fig. 1) is an highly active catalyst for the Stille [10] and Suzuki [11] cross-coupling reactions.

\footnotetext{
* Corresponding author. Tel.: +39 0412348903; fax: +39 0412348967.

E-mail address: scrivanti@unive.it (A. Scrivanti).
}

Spurred by the analogies existing between all these reactions, we have extended our studies to assess the catalytic activity of $\mathbf{1}$ in the Heck arylation reaction. Herein we wish to report the results of our investigations on the catalytic activity of $\mathbf{1}$ in the coupling of aryl bromides with two model olefins such as styrene and butyl acrylate.

\section{Experimental}

All reactions, unless otherwise stated, were carried out under an inert atmosphere (argon). Commercial solvents (Aldrich or Fluka) were purified before the use according to standard procedures [12]. Bromobenzene, 4-bromotoluene, 4-chloroacetophenone, chlorobenzene, styrene, butyl acrylate, $n$-butylamine and thiophenol (Aldrich) were distilled before the use. 4-Bromoacetophenone (Aldrich) was recrystallised from methanol [12]. 4-Bromoanisole, 2-bromo-1,3,5trimethylbenzene, triphenylphosphine were purchased from Aldrich and used as received. Anhydrous sodium acetate, anhydrous potassium carbonate, anhydrous sodium carbonate 


$$
\mathrm{R}^{\rightleftharpoons}+\operatorname{Ar}-\mathrm{X} \underset{\mathrm{Base}}{\stackrel{\text { Cat. }}{\longrightarrow}} \mathrm{R}^{\mathrm{Ar}}
$$

Scheme 1. The Heck reaction.

and mercury were obtained from Fluka. Complex 1 was prepared as described in the literature [13]. The coupling products were identified by their GC-MS and ${ }^{1} \mathrm{H}$ NMR spectra.

GLC analyses were performed on a Agilent 6850 gas chromatograph; GC-MS analyses were performed on a HP 5890 series II gas chromatograph interfaced to a HP 5971 quadrupole mass-detector. ${ }^{1} \mathrm{H}$ NMR spectra were registered on a Bruker Avance 300 NMR spectrometer operating at $300.11 \mathrm{MHz}$.

\subsection{Catalytic experiments}

The experiments were carried out in a magnetically stirred glass reactor $(50 \mathrm{~mL})$ having an inert gas inlet and a side arm closed with a rubber septum for the withdrawing of GLC samples. In a typical experiment (entry 9 of Table 1), under a nitrogen atmosphere, the reactor was charged with $995 \mathrm{mg}$ $(5.0 \mathrm{mmol})$ of 4-bromoacetophenone, $900 \mathrm{mg}(7.0 \mathrm{mmol})$ of butyl acrylate, $450 \mathrm{mg}(5.5 \mathrm{mmol})$ of $\mathrm{NaOAc}, 250 \mu \mathrm{L}$ of a $10^{-3} \mathrm{M}$ solution of complex $\mathbf{1}$ in dimethylacetamide and $5 \mathrm{~mL}$ of dimethylacetamide containing $128 \mathrm{mg}(1.00 \mathrm{mmol})$ of naphthalene as GLC internal standard. The mixture was heated under stirring at $140^{\circ} \mathrm{C}$ for $1 \mathrm{~h}$, then it was rapidly cooled at room temperature and the liquid phase analysed by GLC.

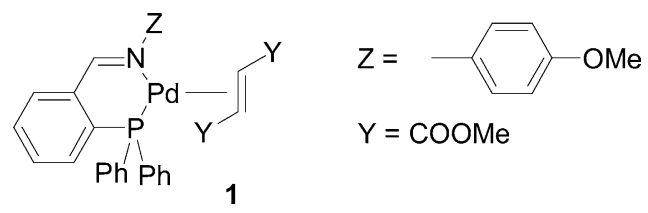

Fig. 1. Chemical structure of complex 1.

\subsection{Kinetic studies and poisoning experiments}

In a typical experiment, the reactor was charged with $785 \mathrm{mg}(5.0 \mathrm{mmol})$ of bromobenzene, $728 \mathrm{mg}(7.0 \mathrm{mmol})$ of styrene, $450 \mathrm{mg}(5.5 \mathrm{mmol})$ of NaOAc and $5 \mathrm{~mL}$ of NMP containing $128 \mathrm{mg}(1.00 \mathrm{mmol})$ of naphthalene as GLC internal standard. The mixture was heated under stirring at $130^{\circ} \mathrm{C}$, then $500 \mu \mathrm{L}$ of a $10^{-3} \mathrm{M}$ solution of complex $1 \mathrm{in} \mathrm{NMP} \mathrm{was}$ quickly introduced in the reactor from the side arm and the course of the reaction monitored by GLC until the substrate conversion was higher than $90 \%$.

In the poisoning experiments, a bromobenzene-styrene reaction mixture prepared according to the procedure above described was allowed to react at $140^{\circ} \mathrm{C}$. After $1 \mathrm{~h}$ a sample of the reacting mixture was withdrawn and analysed by GLC to determine the substrate conversion, then the poison was added from the reactor side arm. Fifteen minutes later, the reacting mixture was analysed again in order to verify the progress of the coupling. Afterwards the reaction was monitored by GLC every $30 \mathrm{~min}$ for $2 \mathrm{~h}$.

\section{Results and discussion}

To test the catalytic activity of $\mathbf{1}$ we used as the model reactions the coupling of 4-bromoacetophenone with styrene or butyl acrylate (Scheme 2).

Preliminary experiments in polar solvents such as dimethylacetamide (DMA) or $N$-methylpyrrolidinone

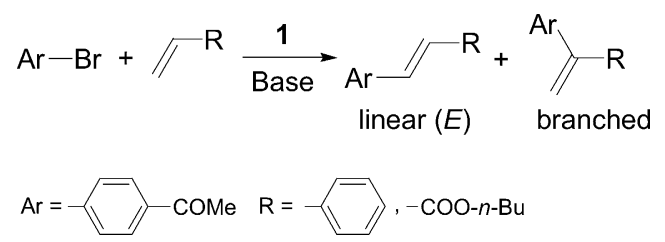

Scheme 2. Heck model reaction.

Table 1

Heck coupling of 4-bromoacetophenone with styrene or butyl acrylate in the presence of complex 1

\begin{tabular}{|c|c|c|c|c|c|c|c|}
\hline Entry & Solvent & Alkene & Base & Time (h) & $T\left({ }^{\circ} \mathrm{C}\right)$ & Yield $(\%)^{\mathrm{a}}$ & $\mathrm{TON}^{\mathrm{b}}$ \\
\hline 1 & NMP & Styrene & $\mathrm{NaOAc}$ & 1 & 130 & $16.1^{\mathrm{c}}$ & 3200 \\
\hline 2 & NMP & Styrene & $\mathrm{NaOAc}$ & 1 & 140 & 73.7 & 14700 \\
\hline 3 & NMP & Butyl acrylate & $\mathrm{NaOAc}$ & 1 & 140 & 63.1 & 12600 \\
\hline 4 & NMP & Butyl acrylate & $\mathrm{K}_{2} \mathrm{CO}_{3}$ & 1 & 140 & 50.4 & 10000 \\
\hline 5 & NMP & Butyl acrylate & $\mathrm{Na}_{2} \mathrm{CO}_{3}$ & 1 & 140 & 10.3 & 2000 \\
\hline 6 & NMP & Butyl acrylate & $n-\mathrm{Bu}_{3} \mathrm{~N}$ & 1 & 140 & 48.7 & 9700 \\
\hline 7 & DMA & Styrene & $\mathrm{NaOAc}$ & 1 & 140 & 43.1 & 8600 \\
\hline 8 & DMA & Styrene & $\mathrm{NaOAc}$ & 2 & 140 & 98.8 & 19700 \\
\hline 9 & DMA & Butyl acrylate & $\mathrm{NaOAc}$ & 1 & 140 & 40.2 & 8000 \\
\hline 10 & DMA & Butyl acrylate & $\mathrm{NaOAc}$ & 2 & 140 & 82.4 & 16500 \\
\hline 11 & DMA & Butyl acrylate & $\mathrm{NaOAc}$ & 3 & 140 & 99.8 & 19900 \\
\hline 12 & $o$-Xylene & Butyl acrylate & $\mathrm{NaOAc}$ & 1 & 140 & 1.8 & 360 \\
\hline
\end{tabular}

Reaction conditions. 4-Bromoacetophenone: $5.0 \mathrm{mmol}$; alkene: $7.0 \mathrm{mmol}$; cat.: $2.5 \times 10^{-4} \mathrm{mmol}$; $\left.\mathrm{ArBr}\right] /[1]$ ] 20,000 ; solvent: $5 \mathrm{~mL}$; base: $5.5 \mathrm{mmol}$.

a Sum of the linear and branched products determined by GLC using naphthalene as internal standard.

b TON: $\mathrm{mol}$ of substrate converted/mol of catalyst.

${ }^{\text {c }}$ Cat.: $5.0 \times 10^{-4} \mathrm{mmol} ;[\mathrm{ArBr}] /[\mathbf{1}]=10,000$. 
Table 2

Influence of the nature of the aryl bromide

\begin{tabular}{|c|c|c|c|c|c|}
\hline Entry & Aryl bromide & Alkene & Time (h) & Yield $(\%)^{\mathrm{a}}$ & $\mathrm{TON}^{\mathrm{b}}$ \\
\hline 1 & $\mathrm{C}_{6} \mathrm{H}_{5} \mathrm{Br}$ & Styrene & 3 & 97.7 & 9700 \\
\hline 2 & $\mathrm{C}_{6} \mathrm{H}_{5} \mathrm{Br}$ & Butyl acrylate & 5 & 49.4 & 4900 \\
\hline 3 & $\mathrm{C}_{6} \mathrm{H}_{5} \mathrm{Br}$ & Butyl acrylate & 24 & 81.6 & 8200 \\
\hline 4 & $4-\mathrm{CH}_{3} \mathrm{C}_{6} \mathrm{H}_{4} \mathrm{Br}$ & Styrene & 24 & 93.9 & 9400 \\
\hline 5 & $4-\mathrm{CH}_{3} \mathrm{C}_{6} \mathrm{H}_{4} \mathrm{Br}$ & Butyl acrylate & 24 & 72.3 & 7200 \\
\hline 6 & 4- $\mathrm{CH}_{3} \mathrm{OC}_{6} \mathrm{H}_{4} \mathrm{Br}$ & Styrene & 24 & $75.5^{\mathrm{c}}$ & 7500 \\
\hline 7 & $4-\mathrm{CH}_{3} \mathrm{OC}_{6} \mathrm{H}_{4} \mathrm{Br}$ & Butyl acrylate & 24 & $84.7^{\mathrm{c}}$ & 8500 \\
\hline 8 & $2-\mathrm{Br}-1,3,5-\left(\mathrm{CH}_{3}\right)_{3} \mathrm{C}_{6} \mathrm{H}_{2}$ & Styrene & 24 & $2.3^{\mathrm{c}}$ & 230 \\
\hline 9 & $2-\mathrm{Br}-1,3,5-\left(\mathrm{CH}_{3}\right)_{3} \mathrm{C}_{6} \mathrm{H}_{2}$ & Butyl acrylate & 24 & $1.5^{\mathrm{c}}$ & 150 \\
\hline
\end{tabular}

Reaction conditions. Aryl bromide: $5.0 \mathrm{mmol}$; alkene: $7.0 \mathrm{mmol}$; cat.: $5.0 \times 10^{-4} \mathrm{mmol}$; $\left.\mathrm{ArBr}\right] /[1]=10,000: 1$; solvent: $\mathrm{NMP}(5 \mathrm{~mL})$; base: $\mathrm{NaOAc}(5.5 \mathrm{mmol})$; T: $140{ }^{\circ} \mathrm{C}$.

a Sum of the linear and branched products determined by GLC using naphthalene as internal standard.

b TON: mol of substrate converted/mol of catalyst.

c Internal standard: $n$-undecane.

(NMP) showed that the reaction requires relatively high temperatures $\left(T>120^{\circ} \mathrm{C}\right)$ in order to proceed with significant rates (see Table 1 ). At $140^{\circ} \mathrm{C}$ the catalyst activity appears very good and the coupling of 4-bromoacetophenone with styrene proceeds giving turnover numbers ( $\mathrm{mol}$ of substrate converted/mol of catalyst) of up to ca. 20,000 in $2 \mathrm{~h}$. In the reaction of 4-bromoacetophenone with butyl acrylate exclusive formation of the linear $(E)$ isomer is observed, instead the coupling of 4-bromoacetophenone with styrene affords a mixture of the linear $(E)$ and of the branched isomer in a 95:5 molar ratio (Scheme 2). This ratio does not vary on changing either the solvent or the base used in the reaction.

The use of highly polar solvents is necessary in order to obtain high reaction rates (compare entries 3, 9 and 12 of Table 1), the highest activity being observed in NMP (compare entry 2 with entry 7 and entry 3 with entry 9 of Table 1 ). As far as the influence of the base is concerned, $\mathrm{NaOAc}$ gives the highest reaction rates (compare entries 3-6). Finally it is to remark that even if the catalyst itself is quite air stable, the reaction does not proceeds unless under an inert atmosphere.

In Table 2 are presented the results of coupling experiments of styrene or butyl acrylate with some other representative aryl bromides. As expected, with aryl bromides not bearing electron-withdrawing substituents the catalytic activity decreases; nevertheless remarkable reaction rates are obtained in the reaction of bromobenzene with styrene (entry 1 of Table 2: ca. 10,000 TON in $3 \mathrm{~h}$ ). The presence of electrondonating groups on the aryl bromide such as a methyl or a methoxy moiety leads to lower reaction rates. However, even working with substrate/catalyst ratios of 10,000:1 high product yields can be achieved in reasonable reaction times $(24 \mathrm{~h})$. Only with the strongly deactivated and sterically hindered 2-bromo-1,3,5-trimethylbenzene the catalyst activity is exceedingly low. It is interesting to note that 4-bromoanisole reacts faster with butyl acrylate than with styrene, while the opposite reactivity pattern is observed with all the other aryl bromides.

There is a great interest in developing new catalytic systems able to activate aryl chlorides, owing to the low cost and availability of this class of substrates. Accordingly, as

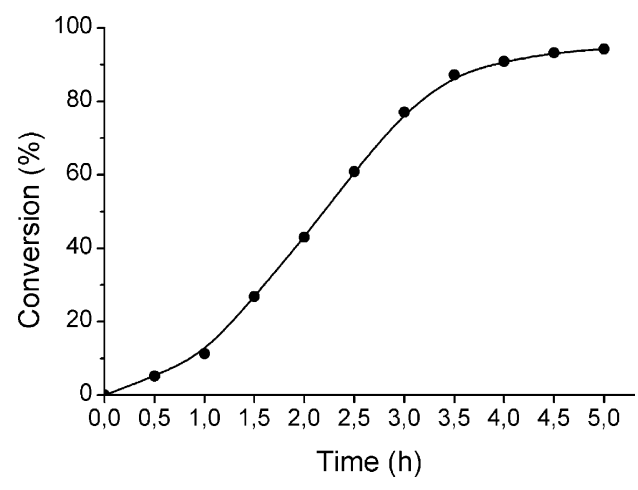

Fig. 2. Conversion vs. time plot for the reaction of bromobenzene with styrene in NMP at $130^{\circ} \mathrm{C}$ (see Section 2).

a further step of our study, we investigated the activity of $\mathbf{1}$ in the coupling of styrene or butyl acrylate with 4chloroacetophenone or chlorobenzene. Unfortunately, almost no reaction is observed: substrate conversions of ca. $1 \%$ are obtained by $24 \mathrm{~h}$ even using substrate/catalyst ratios of 500:1.

The reactivity pattern observed, i.e. very low reaction rates with aryl chlorides versus very high rates with aryl bromides bearing electron-withdrawing substituents is suggestive of a reaction mechanism in which the rate-determining step is the oxidative addition of the aryl halide to a $\operatorname{Pd}(0)$ species. However, complex $\mathbf{1}$ is likely only a precursor of the true catalytic species. In fact, preliminary kinetic studies of the coupling of bromobenzene with styrene (see Section 2) reveal that the reaction exhibits an induction period of about half hour during which the complex 1 likely transforms into the catalytically active species.

Indeed, sigmoidal-shaped kinetics such as the one in Fig. 2 can be taken as evidence of the in situ formation of metallic palladium [14], i.e. that the catalysis is actually heterogeneous. During our experiments we did not observe the formation of palladium black, but it is known that often is very difficult to distinguish between homogeneous and heterogeneous catalytic systems, in particular when colloidal metallic nanoparticles are the active catalytic species. In this connection, it is worth to note that when $\mathrm{Pd}(\mathrm{OAc})_{2}[9 \mathrm{~b}, 9 \mathrm{f}]$ or some 
palladacycles $[6 \mathrm{c}, 7 \mathrm{f}-\mathrm{h}, 15]$ are employed as catalysts in the Heck reaction, there are strong evidences indicating that the actual catalytic species are ligand-free colloidal palladium nanoparticles or clusters and that the starting palladium complex just acts as a catalyst precursor. Therefore, in order to substantiate the intervention of colloidal palladium species in the present case, we deemed appropriate to get a deeper insight on the nature of the catalysis with some poisoning experiments (for a leading review of this subject, see Ref. [14]). Indeed, if the actual catalytic species is a metal particle it would be expected that the addition of a $\mathrm{Hg}$ drop or of neutral molecules such as $\mathrm{PPh}_{3}, \mathrm{CS}_{2}$ or thiophene, able to strongly bind to the particle surface, would stop the reaction [14].

Unfortunately, our experiments led to conflicting results leaving the question about the nature of the true catalytic species without a clear-cut answer. In fact, the addition of a small $\mathrm{Hg}$ drop (ca. 600 or 1000 equivalents with respect to complex 1) to a reacting mixture of bromobenzene and styrene leads to immediate suppression of the catalysis supporting the possible intervention of metal nanoparticles. On the other hand, no effect follows the addition of $\mathrm{PPh}_{3}$ ( 0.05 or 0.10 equivalents) or of thiophenol [16] ( 0.05 or 0.10 equivalents) to reacting mixtures of bromobenzene and styrene.

\section{Conclusions}

In conclusion, the iminophosphine-palladium complexes are highly active catalyst precursors for the Heck coupling of aryl bromides with terminal olefins. The catalyst efficiency compares well with that of other highly active catalysts, even if the catalysis appears particularly sensitive to steric hindrance on the aryl group. Further studies are in progress in order to determine the effect of the structure of the catalyst (effect of the nature of the groups $\mathrm{Z}$ and $\mathrm{Y}$ in Fig. 1) and gain evidences on the nature of the actual catalytic species and the reaction mechanism.

\section{Acknowledgements}

This work has been carried out with the Financial Support of the MIUR (COFIN).

\section{References}

[1] Leading reviews on the Heck reaction: (a) R.F. Heck, in: B.M. Trost, I. Fleming (Eds.), Comprehensive Organic Synthesis, vol. 4, Pergamon Press, Oxford, 1991;

(b) S. Bräse, A. de Meijere, in: F. Dieterich, P.J. Stang (Eds.), Metal Catalyzed Cross Coupling Reactions, Wiley, New York, 1998 (Chapter 3);

(c) G.T. Crisp, Chem. Soc. Rev. 27 (1998) 427;

(d) I.P. Beletskaya, A.V. Cheprakov, Chem. Rev. 100 (2000) 3009;

(e) C.E. Tucker, J.G. de Vries, Top. Catal. 19 (2002) 111; (f) A.B. Dounay, L.E. Overman, Chem. Rev. 103 (2003) 2945.

[2] (a) D.H. Valentine, J.H. Hillhouse, Synthesis (2003) 2437, and references therein;

(b) I. Kondolff, H. Doucet, M. Santelli, Tetrahedron Lett. 44 (2003) 8487;

(c) A.F. Littke, G.C. Fu, Angew. Chem. Int. Ed. 41 (2002) 4177, and references therein;

(d) A.F. Littke, G.C. Fu, J. Am. Chem. Soc. 123 (2001) 6989;

(e) A. Zapf, M. Beller, Chem. Eur. J. 7 (2001) 2908;

(f) V.P.W. Bohm, W.A. Herrmann, Chem. Eur. J. 6 (2000) 1017.

[3] (a) H. Palencia, F. Garcia-Jimenez, J.M. Takacs, Tetrahedron Lett. 45 (2004) 3849;

(b) W.A. Herrmann, K. Öfele, D. von Preysing, S.K. Schneider, J. Organomet. Chem. 687 (2003) 229, and references therein;

(c) A.C. Hillier, S.P. Nolan, Platinum Met. Rev. 46 (2002) 50, and references therein;

(d) K. Selvakumar, A. Zapf, M. Beller, Org. Lett. 4 (2002) 3031.

[4] (a) S. Iyer, G.M. Kulkarni, C. Ramesh, Tetrahedron 60 (2004) 2163; (b) G.A. Grasa, R. Singh, E.D. Stevens, S.P. Nolan, J. Organomet. Chem. 687 (2003) 269, and references therein;

(c) S.B. Park, H. Alper, Org. Lett. 5 (2003) 3209.

[5] (a) D. Yang, Y.-C. Chen, N.-Y. Zhu, Org. Lett. 6 (2004) 1577;

(b) A.S. Gruber, D. Pozebon, A.L. Monteiro, J. Dupont, Tetrahedron Lett. 42 (2001) 7345

[6] (a) M.-H. Huang, L.-C. Liang, Organometallics 23 (2004) 2813; (b) M.E. van der Boom, D. Milstein, Chem. Rev. 103 (2003) 1759, and references therein;

(c) C.S. Consorti, M.L. Zanini, S. Leal, G. Ebeling, J. Dupont, Org. Lett. 5 (2003) 983;

(d) J. Dupont, M. Pfeffer, J. Spencer, Eur. J. Inorg. Chem. (2001) 1917, and references therein;

(e) T. Rosner, J. Le Bars, A. Pfaltz, D.G. Blackmond, J. Am. Chem. Soc. 123 (2001) 1848;

(f) S. Gibson, D.F. Foster, G.R. Eastham, R.P. Tooze, D.J. ColeHamilton, Chem. Commun. (2001) 779.

[7] (a) C.S. Consorti, G. Ebeling, F.R. Flores, F. Rominger, J. Dupont, Adv. Synth. Catal. 346 (2004) 617;

(b) A.K. Gupta, C.H. Song, C.H. Oh, Tetrahedron Lett. 45 (2004) 4113;

(c) L. Botella, C. Najera, Tetrahedron Lett. 45 (2004) 1833;

(d) A. Schnyder, A.F. Indolese, M. Studer, H.-U. Blaser, Angew. Chem. Int. Ed. 41 (2002) 3668;

(e) G.A. Grasa, A.C. Hillier, S.P. Nolan, Org. Lett. 3 (2001) 1077;

(f) R.B. Bedford, C.S.J. Cazin, M.B. Hursthouse, M.E. Light, K.J. Pike, S. Wimperis, J. Organomet. Chem. 633 (2001) 173;

(g) I.P. Beletskaya, A.N. Kashin, N.B. Karlstedt, A.V. Mitin, A.V. Cheprakov, G.M. Kazankov, J. Organomet. Chem. 622 (2001) 89;

(h) M. Nowotny, U. Hanefeld, H. van Koningsveld, T. Maschmeyer, Chem. Commun. (2000) 1877.

[8] (a) V.V. Thakur, N.S.C. Ramesh Kumar, A. Sudalai, Tetrahedron Lett. 45 (2004) 2915;

(b) A.S. Gruber, D. Zim, G. Ebeling, A.L. Monteiro, J. Dupont, Org. Lett. 2 (2000) 1287;

(c) D.E. Bergbreiter, P.L. Osburn, A. Wilson, E.M. Sink, J. Am. Chem. Soc. 122 (2000) 9058.

[9] (a) C.E. Willans, J.M.C.A. Mulders, J.G. de Vries, A.H.M. de Vries, J. Organomet. Chem. 687 (2003) 494;

(b) A.H.M. de Vries, J.M.C.A. Mulders, J.H.M. Mommers, H.J.W. Henderickx, J.G. de Vries, Org. Lett. 5 (2003) 3285;

(c) Q. Yao, E.P. Kinney, Z. Yang, J. Org. Chem. 68 (2003) 7528, and references therein;

(d) K. Kohler, R.G. Heidenreich, J.G.E. Krauter, J. Pietsch, Chem. Eur. J. 8 (2002) 622;

(e) A. Biffis, M. Zecca, M. Basato, Eur. J. Inorg. Chem. (2001) 1131 ;

(f) M.T. Reetz, E. Westermann, Angew. Chem. Int. Ed. 39 (2000) 165 , and references therein. 
[10] A. Scrivanti, U. Matteoli, V. Beghetto, S. Antonaroli, B. Crociani, Tetrahedron 58 (2002) 6881.

[11] A. Scrivanti, V. Beghetto, U. Matteoli, S. Antonaroli, A. Marini, F. Mandoj, R. Paolesse, B. Crociani, Tetrahedron Lett. 45 (2004) 5861.

[12] W.L.F. Armarego, D.D. Perrin, Purification of Laboratory Chemicals, 4th ed., Butterworths-Heinemann, 1996.

[13] S. Antonaroli, B. Crociani, J. Organomet. Chem. 560 (1998) 137.
[14] J.A. Widegren, R.G. Finke, J. Mol. Catal. A 198 (2003) 317.

[15] (a) M.R. Eberhard, Org. Lett. 6 (2004) 2125, and references therein; (b) C. Rocaboy, J.A. Gladysz, Org. Lett. 4 (2002) 1993.

[16] We used thiophenol in the poisoning experiments owing to its high boiling point which ensures its permanence in the reaction solution at $140^{\circ} \mathrm{C}$. 